\title{
Romanian Association of Geomorphologists - evolution of an idea
}

\author{
Maria Rădoane \\ President of Romanian Association of Geomorphologists \\ Ştefan cel Mare University of Suceava \\ Suceava, Romania \\ radoane@usm.ro
}

Well-known geographers such as T. Morariu, V. Mihăilescu, V. Tufescu, N. Al. Rădulescu, P. Coteț, C. Martiniuc, V. Băcăoanu, N. Popp have marked the evolution of geomorphology in Romania and are the ones that gave rise to the idea of forming a group with common preoccupations for the landform study since 1967 [1]. More than fifty years have passed since the publication of the monumental work, "Monografia geografică” (1960), coordinated by two geomorphologists (P. Cotet and C. Martiniuc). The exchange of ideas and information with European geomorphology leaders has become increasingly active after 1965, and so, the desire to focus the efforts of the geomorphology experts on common objectives was shaped more pronouncedly. Grigore Posea, supported by colleagues was the one who put this idea in practice, at the first National Symposium of Geomorphology held in Brassov, in June 1972. The topic of symposium was "Romania's achievements in the landscape study over the last 25 years" which spurred further research on the large relief units. Nor well past a year, that in 1973 no further than a year later, in 1973, the volume "Realizări în geografia românească”, a collection of valuable theoretical studies, synthesizing the issue of relief in Romania, was published. Still today remains a reference work for the relief of Romania.

This brief evocation of the early organization of geomorphology as working group, draws attention on the strong influence of the scientific personalities and on the geomorphology schools of that time, responsible, in my opinion, also, for the prolificacy of publications and ideas, many of them still valid today. No wonder that the geomorphology symposia organized yearly, without interruptions, were real events with debates and confrontations (sometimes bluntly) among opinion leaders on: glaciation problem in Carpathians, periglacial in Romania, river valleys evolution, fluvial terraces, denudation surfaces, etc. Sharp confrontations, reaching even enmity, took place on issues that today seem irrelevant, like the boundaries between major relief units.

Political freedoms obtained after December 1989 brought the legal foundation of the Romanian Association of Geomorphologists, who gain its legal status on 6 April, 1990. The founders (universitarians, researchers, geography teachers, experts from other domains, interested in landform knowing) gathered at the Faculty of Geography, Bucharest and the first president in the person of Professor Grigore Posea was elected. On that occasion, the leadership, the first president and vice-presidents: Ioan Mac, Dan Bălteanu, Ioniţă Ichim were designated. In the same year, the association obtained legal personality (foundation documents were published in Revista de Geomorfologie, no.1, 1997) [2].

We appreciate that the moment of RAG constitution took place less than one year after the foundation of International Association of Geomorphologists (IAG/AIG), respectively, 1989, when the second International Conference on Geomorphology (Frankfurt/Main, Germany) was organized. Romanian Association of Geomorphology (RAG) adhered at IAG/AIG in 1997, joining 61 geomorphology professional associations from the same number of countries.

Yearly and sometimes biannual, the Romanian geomorphologists (RAG affiliated or no) have gathered during Symposia. Two pictures are suggestive to portray the geomorphologist group that marked those early decades of our association (Figs 1 and 2).

During their annual and biannual Symposium meetings the Romanian geomorphologist discussed key issues of the relief in Romania, concepts and research methods and even challenges from other domains with interest on landforms. The list of Symposiums that took place over time is presented on www.geomorfologie.ro. The map (Fig. 3) shows the spatial distribution of localities were the RAG symposia were organized and at the same time illustrates the development, the tradition and the strength of the group of geomorphologists in Romania. As detailed information is not available (for example, the programs of all these manifestations) we weren't able to perform an analysis regarding the evolution of the addressed subjects. One of the oldest programs found in the archives of colleagues was the one from the 1993 symposium. By comparing the topics with the ones from 2013 (20 years later) we have found a pretty broad change regarding the dynamic of topics and of framing in the big domains of geomorphology, historicist (preoccupied by palaeoevolution) and functional (preoccupied by understanding the modeling processes). 


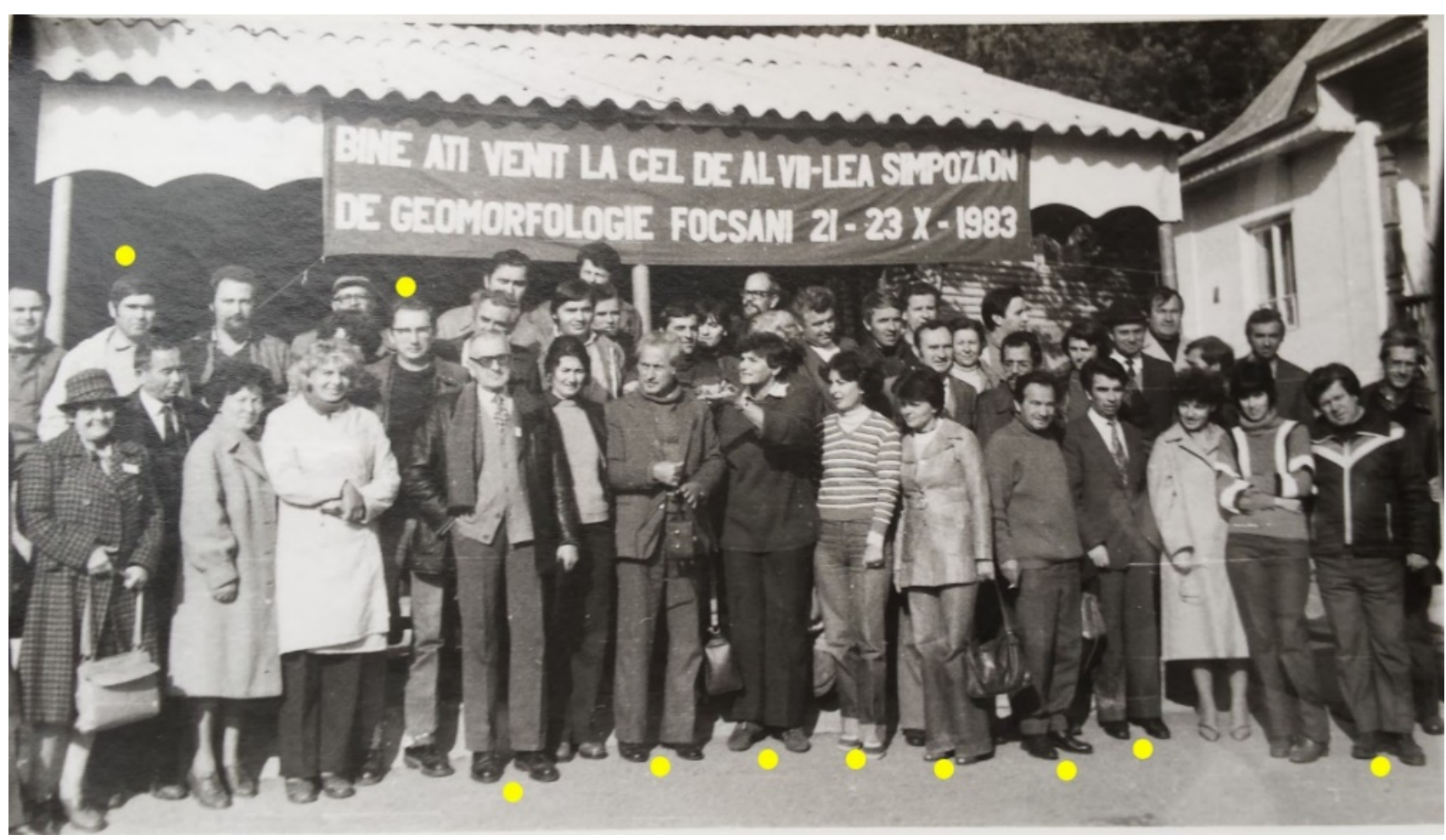

Fig. 1. Participants to the Seventh National Symposium of Geomorphology, Focșani, 1983. From left to right following the yellow dot: Dan Bălteanu, Emil Vespremeanu, Nicolae Popp, Grigore Posea, Maria Pătroescu, Mihaela Dinu, Maria Sandu, Nicolae Popescu, Ioniță Ichim, Mihai Ielenicz.

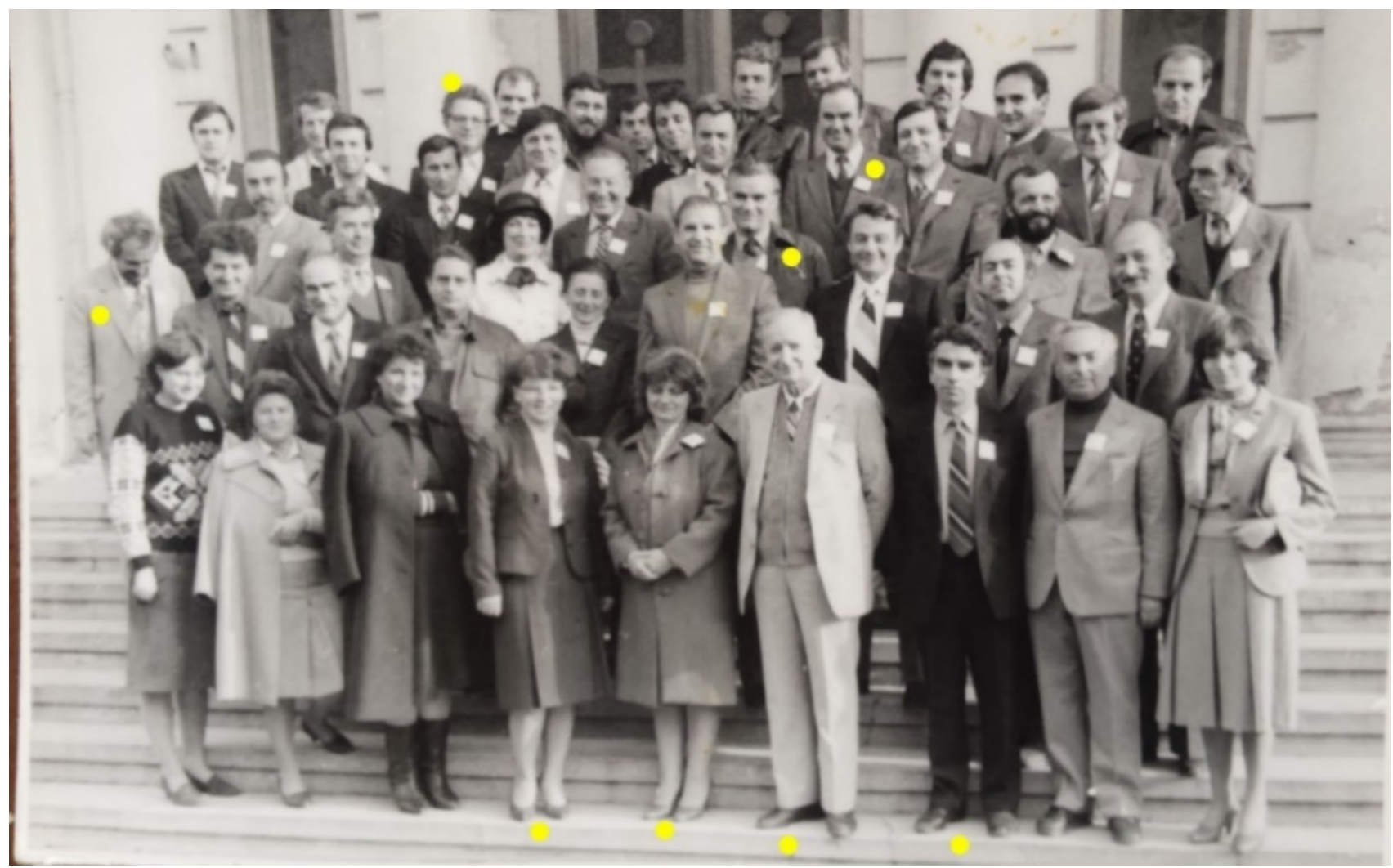

Fig. 2. Participants to the Provenance and sediment delivery symposium, Piatra Neamț, 1986. From left to right by following the yellow dot, above: Virgil Surdeanu, Nicolae Rădoane, Ioan Mac, Ion Zăvoianu. Idem, down: Maria Rădoane, Florina Grecu, Constantin Martiniuc, Ioniță Ichim

In 1993 the historicist subjects counted about $70 \%$ of the geomorphologists preoccupation, while in 2013, only about 5\%. As we will show below, it was a natural phenomenon, in perfect sync with international trends in geomorphology evolution. 
After year 1990, 9 presidents have succeeded, in the lead of RAG: Grigore Posea (University of București); Ioan Mac (University Babeș-Bolyai Cluj-Napoca), Nicolae Popescu (University of București), Emil Vespremeanu (University of București), Nicolae Josan (University of Oradea), Virgil Surdeanu (University Babeș-Bolyai ClujNapoca), Petru Urdea (West University of Timişoara), Maria Rădoane (University Ștefan cel Mare of Suceava). From this presentation can be noted an interesting spatial distribution, sign that the geomorphological research centers have claimed both large universities and also the medium size ones.

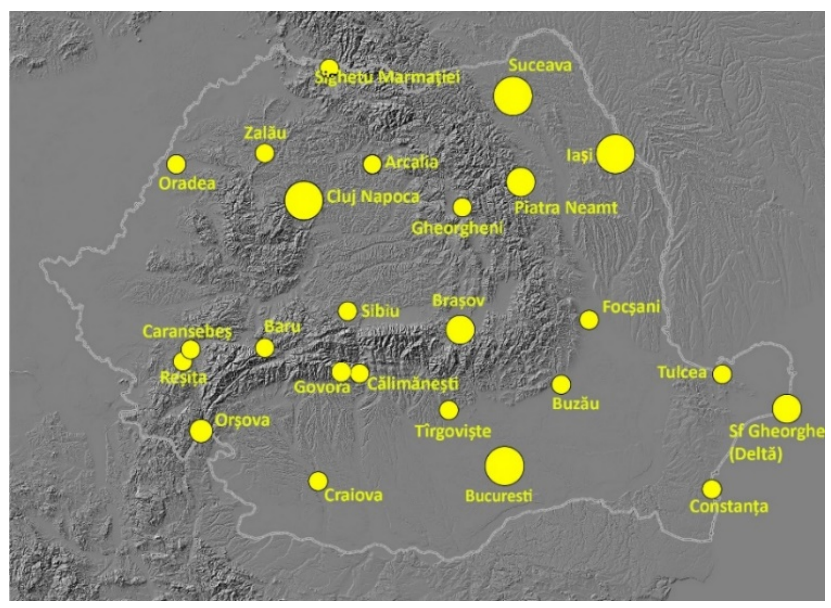

Fig. 3. Spatial distribution of the localities where the National Symposium of Geomorphology was organized, from 1972 until present. At Iași, Cluj, București and Suceava were organized at least 3 symposia, at Brașov, Piatra Neamț, Orşova and Sf.Gheorghe (Danube Delta) 2 symposia, in the rest of the localities on the map, 1 symposium.

From 1990, RAG is editing the Revista de Geomorfologie Journal (www.revistadegeomorfologie.ro) which reached no. 18. Following the same line as the research topics presented at the symposia, the content of Revista de Geomorfologie Journal from 1990 until present reflects the perfect synchronization of the theoretical concepts and research methods with those manifested at international context [3]. It seems very relevant to recall a passage from an article by [4] to illustrate the importance of contacts and relations at international level, the connection of Romanian geomorphology to the trends and preoccupations presented in international context needed to elaborate our own analysis models in the landform domain. Despite many difficulties to direct access the international scientific events before 1990, Romanian presence at the high meetings of the international geomorphological community (as it was the first International Conference of Geomorphologists, Manchester, 1985) was reported, and some evidences of this are impressive. We present below a passage of the article mentioned above, published in Terra Journal, from which we conclude that Romanian geomorphologists had the same scientific concerns as their international counterparts, but less support in what regards the logistical aspects of their work:

" Because the title of this article (Geomorphology in the 3rd Millennium threshold, n.n.) it may seem strange to most, I want to start with the confession that it plagued me for nearly a decade. Not only expression itself, but rather, the actual coverage of the history of our science and its path. It has happened that after my participation at the first International Geomorphology Conference (Manchester, 1985) when I saw the largest exhibition of books and journals from world in the domain, and numerous exhibitions of equipment and technology work, included those presented by NASA have constituted without any doubt, unimaginable performances. And as a corollary of these unique premieres for the most of geomorphologists, to works developed under NASA management were discussed by all audience, before being published in a final form: Geomorphology from space - A global overview of regional landforms (eds. N. M. Short and R.W. Blair Jr) and Global Mega-Geomorphology (ed. R.S. Hayden). The fact that NASA «entered» on the land of geomorphology was undoubtedly a sigh that our domain is located at a turning point". The same feeling somewhat overwhelming I had myself when I met the way in which EGU General Assembly is organized, back in 2008.

Not all the topics of geomorphology enjoyed the same trend overtime. For example, the domain of hillslopes frequently draw attention of the Romanian geomorphologists before 1989 who wanted to understand the relation between slope, deposits and processes. Before 1990, the hillslope morphological category passed in the background, and the hillslope processes under the name of hazards have become the focus of geomorphological investigations. Other domains (fluvial, coastal, periglacial, soil erosion) have experienced a remarkable transformation in terms of research methodology, with substantial conclusions based on measured and quantified data. Noteworthy is the increased preoccupation after year 2000 in geomorphological palaeoenvironments reconstruction from Early Quaternary by developing the absolute dating techniques. In addition, new domains like geomorphometry, have developed in Romania, due to the development of information technology.

In conclusion, the main qualitative thresholds in landform knowledge were crossed also by the Romanian geomorphologists due to: "the quantitative revolution", the focus on the study of the geomorphological processes and landform dynamics at medium and small scales, the access to the latest technologies needed for observations and measurements on processes and landforms, and to the access to absolute dating which allows the reinterpretation of the landform evolution on a larger temporal scale. All these have supported the affirmation of a group of young geomorphologists with interdisciplinary education and excellent analytical skills which forms today the most prolific part of our association in what regards scientific results. An illustration of this is the recent publication of the Landform Dynamics and Evolution in Romania (edited by M. Rădoane and A. Vespremeanu-Stroe), Springer, 2016.

\section{REFERENCES}

[1] E. Vespremeanu, “40 ani de geomorfologie organizată în România”, Revista de Geomorfologie, vol. 7, pp. 5-7, 2005. (in Romanian)

[2] G. Posea, "Cuvânt inainte”, Revista de Geomorfologie, vol. 1, no. pp. 1-2, 1997. (in Romanian) 
[3] M. Rădoane, A. Vespremeanu-Stroe, "Introduction” in Landform Dynamics and Evolution in Romania, M. Rădoane, A. Vespremeanu-Stroe, Eds. Springer, 2017, pp. 1-11.
[4] I. Ichim, "Geomorfologia in pragul Mileniului III”, Terra, vol. 25, no. 1-4, pp. 83-90, 1993. (in Romanian) 